\title{
A comparison of the erythrocyte sedimentation rate and plasma viscosity in detecting changes in plasma proteins
}

\author{
R. M. HUTCHINSON ${ }^{1}$ AND R. D. EASTHAM \\ From the Department of Haematology, Frenchay Hospital, Bristol
}

SUMMARY The Westergren erythrocyte sedimentation rate (ESR) and plasma viscosity were compared in 114 patients and their correlations with total and differential plasma protein fractions were analysed.

There is a linear correlation between these two screening tests. Higher correlation coefficients were obtained between the plasma viscosity and fibrinogen and alpha and gamma globulins than with the ESR. Albumin affected the two tests in opposite directions. The ESR was falsely increased by a fall in haemoglobin even within two standard deviations from the mean.

Both tests gave an appreciable number of incorrect values-the plasma viscosity in 21 cases and the ESR in 33. The cause for these is discussed. It is concluded that the plasma viscosity is the more sensitive and reliable measure of changes in acute phase protein reactants and more useful for monitoring clinical progress.

Following tissue injury or inflammation, the commonest alteration in the concentrations of the various plasma proteins is the so-called acute phase plasma protein response. The protein fractions which increase include fibrinogen (its concentration can double within 24 hours), alpha-proteins (alpha-1 antitrypsin, alpha-1 anti-chymotrypsin, and alpha-1 acid glycoprotein), caeruloplasmin, and the second, third, and fourth components of complement. Subsequently, there is an increase in alpha-2 macroglobulin, followed by an increase in the plasma gamma globulins. Unlike these positive acute phase reactants, albumin is a negative acute phase reactant and tends to diminish in concentration. In a more chronic pathological process there may be a predominance of the negative phase response, with normal or slightly increased fibrinogen levels, normal or decreased albumin concentration, and an increase in plasma gamma globulin concentrations following antigenic exposure, beginning about 10-14 days after the initial injury (Alper, 1974).

By estimating the erythrocyte sedimentation rate (ESR) and plasma viscosity (PV) in parallel with a

'Present address and requests for reprints: Department of Haematology, Leicester Royal Infirmary

Received for publication 1 September 1976 series of total and differential protein fraction estima tions on blood samples obtained from a group of patients, an attempt has been made to determine which of these two tests gave the most direct indication of changes in the plasma proteins. In this way, it was hoped that it might be possible to decide which of these two simple screening tests would be most useful in the assessment of severity and duration of disease known to alter the normal plasma protein pattern.

\section{Methods and materials}

Blood samples were obtained from 114 unselected patients attending a general medical and rheumatology outpatient clinic. Their clinical diagnoses were not considered during this investigation. The ESR was determined within four hours of collection by the Westergren technique (as described by the International Committee for Standardization in Hematology, 1973), and the normal range was taken as $0-5 \mathrm{~mm}$ for men and $0-7 \mathrm{~mm}$ for women, when read after one hour. Although Bull and Brecher (1974) have shown the Wintrobe method better for picking up changes in macromolecules in blood, Westergren is better for detecting changes in established disease (where there is marked increase 
of macromolecules) (Dacie and Lewis, 1975). The coefficient of variation obtained from 10 replicate estimations on a blood sample with an ESR of $50 \mathrm{~mm} /$ hour was $6.4 \%$.

The PV was estimated at $25^{\circ} \mathrm{C}$ by means of a capillary viscometer (Harkness, 1971) with a normal range for both sexes of 1.5-1.72 $\mathrm{cP}$ and a coefficient of variation for the method of $1.06 \%$.

Full blood counts were carried out on a Coulter ' $S$ ' Counter, male patients being considered as anaemic when their haemoglobin level was less than $13 \mathrm{~g} / \mathrm{dl}$, the corresponding figure being $11.5 \mathrm{~g} / \mathrm{dl}$ for females (Dacie and Lewis, 1975).

Total and differential serum protein levels were estimated by AutoAnalyzer and cellulose acetate electrophoresis (Varley, 1967). Fibrinogen concentrations were measured in EDTA plasma by a nephelometer, with a normal range of $1 \cdot 5-4.0 \mathrm{~g} / \mathrm{l}$ (Watson, 1961).

\section{Results}

In Table 1 regression analyses are shown comparing ESR results with the corresponding plasma viscosity, serum total globulin, and plasma fibrinogen. Because a low haematocrit caused false positive results with the ESR, further regression analyses were carried out on non-anaemic patients only. These were expanded to embrace the differential globulin concentrations and are shown in Table 2. The corresponding analyses comparing plasma viscosity results with serum protein fractions and plasma fibrinogen are shown in Table 3.

A significant inverse correlation between serum

Table 1 Regression analyses to show linear correlations between ESR and plasma viscosity and protein fractions, without exclusion of anaemic patients

\begin{tabular}{llrll}
\hline & r & No. & \multicolumn{1}{l}{$S E$} & P \\
\hline ESR and plasma viscosity & 0.65 & 97 & 0.12 & $<0.001$ \\
ESR and total globulin & 0.16 & 114 & 0.09 & 0.1 \\
ESR and fibrinogen & 0.25 & 97 & 0.11 & $<0.1>0.05$ \\
\hline
\end{tabular}

Table 2 Regression analyses to show linear correlations between ESR and plasma viscosity and protein fractions, after exclusion of results from anaemic patients

\begin{tabular}{lllll}
\hline & r & No. & $S E$ & P \\
\hline ESR and plasma viscosity & 0.69 & 73 & 0.12 & $<0.001$ \\
ESR and total globulin & 0.52 & 57 & 0.13 & $<0.001$ \\
ESR and fibrinogen & 0.55 & 73 & 0.12 & $<0.001$ \\
ESR and gamma globulin & 0.52 & 53 & 0.12 & $<0.001$ \\
ESR and alpha-2 globulin & 0.40 & 53 & 0.14 & $<0.1>0.05$ \\
ESR and total alpha & 0.089 & 53 & 0.14 & $<0.1$ \\
$\quad$ globulin & & & & \\
\hline
\end{tabular}

Table 3 Regression analyses to show linear correlations between plasma viscosity and protein fractions, without exclusion of results from anaemic patients

\begin{tabular}{lllll}
\hline & $\mathrm{r}$ & No. & $S E$ & $\mathrm{P}$ \\
\hline $\begin{array}{l}\text { Plasma viscosity and total } \\
\text { globulin }\end{array}$ & 0.76 & 114 & 0.09 & $<0.001$ \\
$\begin{array}{l}\text { Plasma viscosity and } \\
\text { fibrinogen }\end{array}$ & 0.81 & 114 & 0.09 & $<0.001$ \\
$\begin{array}{l}\text { Plasma viscosity and } \\
\text { gamma globulin }\end{array}$ & 0.56 & 114 & 0.09 & $<0.001$ \\
$\begin{array}{l}\text { Plasma viscosity and total } \\
\text { alpha globulin }\end{array}$ & 0.58 & 114 & 0.09 & $<0.001$ \\
$\begin{array}{c}\text { Plasma viscosity and } \\
\text { alpha-2 globulin }\end{array}$ & 0.51 & 114 & 0.09 & $<0.001$ \\
\hline
\end{tabular}

Table 4 Correlation coefficients ( $r$ ), standard error $(S E)$, and probabilities for albumin against total globulin and fibrinogen

\begin{tabular}{lcccl}
\hline & r & No. & $S E$ & P \\
\hline 1 Albumin $v$ total globulin & -0.58 & 114 & 0.09 & $<0.001$ \\
2 Albumin $v$ fibrinogen & -0.343 & 114 & 0.09 & $<0.1>0.05$ \\
3 Fibrinogen $v$ globulin & 0.381 & 114 & 0.09 & $<0.1>0.5$ \\
\hline
\end{tabular}

albumin and globulin concentrations and a marginally significant inverse correlation between serum albumin and plasma fibrinogen concentrations were found (Table 4), with a direct correlation between plasma fibrinogen and serum globulin.

The incidence of results above or below the normal limits for each test (ESR and PV) when the serum globulin and/or plasma fibrinogen concentrations were normal or increased above normal was compared (Table 5). The PV result was raised above normal when both serum globulin and plasma fibrinogen results fell within normal limits in one blood sample, while PV results fell below the normal upper limit in the presence of increased plasma fibrinogen and/or serum globulin concentration in 20 blood samples. The ESR was increased above normal in the presence of normal concentrations of plasma fibrinogen and serum globulin in 21 samples, and was below the upper normal limits when plasma fibrinogen and/or serum globulin concentrations were abnormally increased in 12 samples.

\section{Discussion}

There is a direct correlation between ESR and PV which can be described by the equation $y=$ $107.08 x-162.47$, where $y=E S R$ in $\mathrm{mm}$ at one hour and $\mathrm{x}=\mathrm{PV}$ in centipoise at $25^{\circ} \mathrm{C}, \mathrm{r}=0.69$ (Figure). Crockson and Crockson (1974), using a different method for PV estimation and a modified Westergren ESR technique, reported a similar direct correlation, with $r=0.47$. 
Table 5 Failures of the Westergren ESR and plasma viscosity to predict fibrinogen and globulin concentration

\begin{tabular}{|c|c|c|c|c|c|c|c|}
\hline & \multicolumn{4}{|c|}{ Concentration of fibrinogen and globulin } & \multirow[t]{2}{*}{ Totals } & \multirow[t]{2}{*}{ True result } & \multirow[t]{2}{*}{ False result } \\
\hline & $\begin{array}{l}\text { Fib. normal } \\
\text { Glob. normal }\end{array}$ & $\begin{array}{l}\text { Fib. raised } \\
\text { Glob. normal }\end{array}$ & $\begin{array}{l}\text { Fib. normal } \\
\text { Glob. raised }\end{array}$ & $\begin{array}{l}\text { Fib. raised } \\
\text { Glob. raised }\end{array}$ & & & \\
\hline $\begin{array}{l}\text { ESR raised } \\
\text { PV raised }\end{array}$ & $\mathbf{0}$ & 28 & $\mathbf{0}$ & 21 & 49 & 49 & $\mathbf{0}$ \\
\hline $\begin{array}{l}\text { ESR normal } \\
\text { PV raised }\end{array}$ & 1 & 2 & 1 & 1 & 5 & 0 & 5 \\
\hline $\begin{array}{l}\text { ESR raised } \\
\text { PV normal }\end{array}$ & 21 & 10 & 2 & 0 & 33 & & 33 \\
\hline $\begin{array}{l}\text { ESR normal } \\
\text { PV normal }\end{array}$ & 19 & 3 & 2 & 3 & 27 & 19 & 8 \\
\hline Totals & 41 & 43 & 5 & 25 & 114 & 68 & 46 \\
\hline
\end{tabular}

Summary of table

Plasma viscosity gave false positive results with normal proteins in one and false negative results with raised globulin and/or fibrinogen in 20 ESR gave false positive results with normal proteins in 21, and false negative results with raised globulin and/or fibrinogen in 12.

The plasma viscosity yielded false results in 21 cases.

The ESR yielded false results in 33 cases.

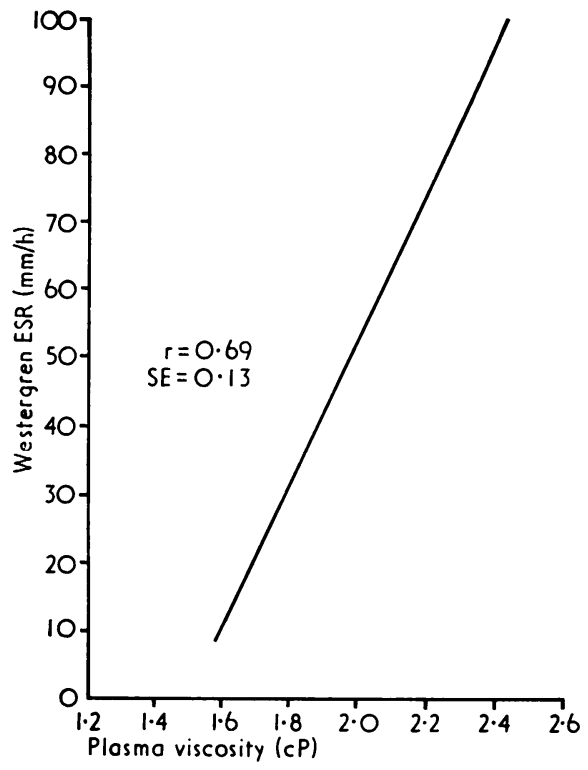

Figure Relationship between ESR and plasma viscosity, derived by regression analysis of the two parameters on each sample of blood from 73 non-anaemic persons. The relationship is significant at the $5 \%$ level

As the correlations with individual protein fractions were examined, it was found that when anaemic and non-anaemic patients were considered together, the ESR gave much lower correlation values than did the PV results, and when the anaemic patients' results were excluded correlations with the
ESR results improved but were still lower than corresponding PV correlations (Tables 1, 2, and 3). The highest direct correlation was found between PV and plasma fibrinogen (Table 3). This confirms the finding of Eastham and Morgan (1965).

The ESR is a test in which various different hydrophilic protein fractions cause red cell aggregation, and the rate of red cell sedimentation depends directly on the size of aggregates formed (the rate of sedimentation being directly proportional to the square of the radius of the aggregate-Stokes' Law), and the rate at which these aggregates or pseudoagglutinations are formed. The sedimentation of red cells in plasma is complex and consists of three phases, namely, aggregation, phase of maximum sedimentation, and packing which vary greatly and which are interrelated in a complicated manner (Eastham et al., 1958). Thus changes in plasma protein pattern cause red cell aggregation, and the rate of fall of aggregates is affected by the initial haematocrit. Plasma fibrinogen, total globulin, and macroglobulins all enhance red cell aggregation and sedimentation (Scherer et al., 1975). In this study, however, the ESR failed to give a highly significant correlation with the total alpha proteins. Their rise in concentration anticedes the changes in fibrinogen occurring in the acute phase reaction. Thus Harkness (personal communication, 1975) found the changes in the ESR to lag behind those in PV by 24 to 48 hours after an acute myocardial infarction.

Albumin normally disperses rouleaux and thus retards red cell aggregation and hence tends to reduce the ESR.

The PV is also a test used to detect changes in plasma protein pattern; the more intensely hydro- 
philic proteins with high molecular weight, such as fibrinogen or macroglobulins, increase plasma viscosity to a greater extent weight for weight than albumin. However, an increase in any plasma protein fraction, including increase in albumin concentration, directly increases plasma viscosity (Eastham and Morgan, 1965). Thus the plasma albumin concentration affects the two tests differently. Harris (1972) was able to show that the raised ESR frequently found in some geriatric patients was directly related to reduced plasma albumin levels which, by promoting rouleaux, increases red cell aggregation in the presence of normal concentrations of fibrinogen and globulin. The plasma viscosity values in these patients fall within the normal range. Recently the importance of low plasma viscosity values below the lower normal limit as an indication of low immunoglobulin levels has been described (Basterfield, 1975) and adds to the value of this test; there is no such thing as an ESR below normal.

In the present study the effect of anaemia on the ESR as well as the effects of the protein fractions have already been mentioned (Tables 1 and 2). The normal haematocrit is different for adult males and females, and this is reflected in the differences between the normal upper limits for the ESR in the two sexes. We found that even when the haematocrit lay within 2 standard deviations below the mean, the ESR was artificially raised given the same total globulin and fibrinogen. In addition, valid results are obtained only if the ESR is performed within 4 hours of collection, and results obtained are affected by the ambient temperature at which the test is performed.

Plasma viscosity is not affected directly by changes in the haematocrit, nor is it affected by storage of plasma for up to 48 hours (Harkness, 1971).

When the ESR and PV results are compared with plasma fibrinogen and/or globulin concentrations simply defined as above or below the upper limits of normal, it was found that both tests gave 'false negative' and 'false positive' results (Table 5). The ESR gave more 'false positive' results in the presence of normal plasma protein results even when anaemic patients were excluded, and the PV gave more 'false negative' results in the presence of increased plasma fibrinogen and/or globulin value. It is probably therefore of significance that there was an inverse correlation between serum albumin values and serum total globulin concentrations. Many conditions in which raised plasma globulin levels are found are associated with falling serum albumin concentrations. Such changes in plasma protein patterns would tend to increase the ESR by removing the anti-aggregation effects of albumin, while at the same time reducing the plasma viscosity in proportion to the fall in serum albumin.
It is considered that the $\mathrm{PV}$ is a simple test rapidly carried out, with good precision, which is sensitive to acute phase protein reactants and is useful in the monitoring of clinical progress. The ESR is also a simple test but it has the disadvantage of a time limit for performance, and the complications caused by abnormally high or low haematocrit values with no established satisfactory method for correction for anaemia, and no way of detecting abnormal protein patterns in the presence of raised haematocrit.

We thank the scientific and technical staff at Frenchay Laboratories and the medical and nursing staff at Bristol Royal Infirmary.

\section{References}

Alper, C. A. (1974). Plasma protein measurements as a diagnostic aid. New England Journal of Medicine, 291, 287-290.

Basterfield, P. J. (1975). Plasma viscosity as a routine replacement for the E.S.R. 10th Coulter Electronics Symposium.

Bull, B. S. and Brecher, G. (1974). An evaluation of the relative merits of the Wintrobe and Westergren Sedimentation Methods, including hematocrit correction. American Journal of Clinical Pathology, 62, 502-510.

Crockson, R. A. and Crockson, A. P. (1974). Relationship of the erythrocyte sedimentation rate to viscosity and plasma proteins in rheumatoid arthritis. Annals of Rheumatic Diseases, 33, 53-56.

Dacie, J. V. and Lewis, S. M. (1975). Estimation of the erythrocyte sedimentation rate. In Practical Haematology, 5th edition, pp. 580-582. Churchill Livingstone, Edinburgh.

Eastham, R. D. (1967). Rapid detection of abnormally raised plasma globulin and fibrinogen by means of plasma viscosity. Proceedings of the 10th Congress of the European Society of Haematology, Strasbourg 1965, Part II, pp. 955-958. Karger, Basle.

Eastham, R. D., Denson, K. W. E., and Evans, D. A. (1958). The effects of sodium citrate and potassium ammonium oxalate on the erythrocyte sedimentation rate. Acta Medica Scandinavica, 161, 277-288.

Eastham, R. D. and Morgan, E. H. (1965). Plasma viscosity in clinical laboratory practice. Journal of Medical Laboratory Technology, 22, 70-73.

Harkness, J. (1971). The viscosity of human plasma: its measurement in health and disease. Biorrheology, 8, 171-193.

Harris, G. J. (1972). Plasma viscosity and E.S.R. in the elderly. Journal of Medical Laboratory Technology, 29, 405-410.

International Committee for Standardization in Hematology (1973). Reference method for the erythrocyte sedimentation rate (ESR) test on human blood. British Journal of Haematology, 24, 671-673.

Scherer, R., Morarescu, A., and Ruhenstroth-Bauer, G. (1975). Die spezifische Wirkung der Plasmaproteine bei 
der Blutkörperchensenkung. Eine Analyse der Korrelationskoeffizienten von Blutkörperchensenkungsgeschwindigkeit und den Konzentrationen von zwanzig Plasmaproteinen bei Gesunden und Kranken, insbesondere nach Herzinfarkt. Klinische Wochenschrift,
53, 265-273.

Varley, H. (1967). Practical Clinical Biochemistry, 4th edition, pp. 246-252. Heinemann, London.

Watson, D. (1961). Rapid estimation of fibrinogen (Letter). British Medical Journal, 1, 903-904.

\section{Reports and Bulletins prepared by the Association of Clinical Biochemists}

The following reports and bulletins are published by the Association of Clinical Biochemists. They may be obtained from The Publishing Department, British Medical Journal (ACB Technical Bulletins), B.M.A. House, Tavistock Square, London WC1H 9JR. Overseas readers should remit by British Postal or Money Order.

SCIENTIFIC REPORTS (price $\boldsymbol{£ 1 . 0 0 / \$ 2 . 0 0 ~ e a c h ) ~}$

3 Automatic Dispensing Pipettes: an assessment of 35 commercial instruments September 1967 P. M. G. BROUGHTON, A. H. GOWENLOCK, G. M. WIDDOWSON, and R. A. AHLQUIST

4 An Evaluation of five Commercial Flame Photometers suitable for the Simultaneous Determination of Sodium and Potassium March 1970 P. M. G. BROUGHTON and J. B. DAWSON

SCIENTIFIC REVIEWS (price $£ 1 \cdot 00 / \$ 2.00$ each)

1 The Assessment of Thyroid Function March 1971 F. V. FLYNN and J. R. HOBBS

2 Renal Function Tests Suitable for Clinical Practice January 1972 F. L. MTCHELL, N. VEALL, and R. W. E. WATTS

3 Biochemical Tests for the Assessment of Fetoplacental Function May 1975 C. E. WILDE and R. E. OAKEY

4 Test of Exocrine Pancreatic function, March 1977, A. H. GOWENLOCK

TECHNICAL BULLETINS (price $£ 1 \cdot 00 / \$ 2.00$ each)

9 Determination of Urea by AutoAnalyzer November 1966 RUTH M. HASLAM

11 Determination of Serum Albumin by AutoAnalyzer using Bromocresol Green October 1967 B. E. NORTHAM and G. M. WIDDOWSON

13 An Assessment of the Technicon Type II Sampler Unit March 1968 B. C. GRAY and G. K. McGowAN

14 Atomic Absorption Spectroscopy: an outline of its principles and a guide to the selection of instruments May 1968 J. B. DAWSON and P. M. G. BROUGHTON

15 A Guide to Automatic Pipettes (2nd edition) June 1968 P. M. G. BROUGHTON

16 A Guide to Automation in Clinical Chemistry May 1969 P. M. G. BROUGHTON

17 Flame Photometers: a comparative list of 17 instruments readily available in Britain August 1969 P. WILDING

19 Spectrophotometers: a comparative list of low-priced instruments readily available in Britain May 1970
C. E. WILDE and P. SEWELL

20 Quantities and Units in Clinical Biochemistry June 1970 P. M. G. BROUGHTON

21 Filter Fluorimeters: A comparative list of 18 instruments September 1970 H. BRAUNSBERG and S. S. BROWN 22 Bilirubin Standards and the Determination of Bilirubin by Manual and Technicon AutoAnalyzer Methods January 1971 BARBARA BILLING, RUTH HASLAM, and N. WALD

23 Interchangeable Cells for Spectrophotometers and Fluorimeters September 1971 S. S. BROWN and A. H. GOWENLOCK

24 Simple Tests to Detect Poisons March 1972 B. W. MEADE et al.

25 Blood Gas Analysers May 1972 K. DIXON

26 Kits for Enzyme Activity Determination September 1972 s. B. ROSALKI and D. TARLOW

27 Assessment of Pumps Suitable for Incorporation into Existing Continuous Flow Analytical Systems November 1972 A. FLECK et al.

28 Routine Clinical Measurements of Transferrin in Human Serum September 1973 K. DIXON

29 Control Materials for Clinical Biochemistry (5th edition) September 1973 J. F.STEVENS

30 Notes on the Quality of Performance of Serum Cholesterol Assays September 1973 S. S. BROWN

31 Determination of Uric Acid in Blood and in Urine July 1974 R. W. E. WATTS

32 A Survey of Amino Acid Analysers Readily Available in the United Kingdom September 1974 J. E. CARLYLE and P. PURKISS

33 Definitions of some Words and Terms used in Automated Analysis November 1974 A. FLECK, R. ROBINSON, S. S. BROWN, and J. R. HOBBS

34 Measurement of Albumin in the Sera of Patients January 1975 LINDA SLATER, P. M. CARTER, and J. R. HOBBS

35 Investigation of the Validity of Temperature Correction Factors for Serum Aspartate and Alanine Transaminases March 1975 s. B. ROSALKI et al.

36 Factors Influencing the Assay of Creatinine November 1975 J. G. H. COOK 